\title{
A neutral trehalase gene from Candida albicans: molecular cloning, characterization and disruption
}

\author{
Raimund Eck, ${ }^{1}$ Clemens Bergmann, ${ }^{1}$ Karl Ziegelbauer, ${ }^{2}$ \\ Wolfgang Schönfeld ${ }^{2}$ and Waldemar Künkel ${ }^{1}$
}

Author for correspondence: Raimund Eck. Tel: +49 3641 656852. Fax: +493641656652.

e-mail: reck@leutra.imb-jena.de

\footnotetext{
1 Hans-Knöll-Institut für Naturstoff-Forschung e.V., Abteilung Mykologie, Beutenbergstraße 11 . D-07745 Jena, Germany

2 Bayer AG, PH-R

Antiinfectiva Forschung I, D-42096 Wuppertal Germany
}

\begin{abstract}
A neutral trehalase gene, NTC1, from the human pathogenic yeast Candida albicans was isolated and characterized. An ORF of 2724 bp was identified encoding a predicted protein of 907 amino acids and a molecular mass of $104 \mathrm{kDa}$. A single transcript of approximately $3.2 \mathrm{~kb}$ was detected by Northern blot analysis. Comparison of the deduced amino acid sequence of the C. albicans NTC1 gene product with that of the Saccharomyces cerevisiae NTH1 gene product revealed $57 \%$ identity. The NTC1 gene was localized on

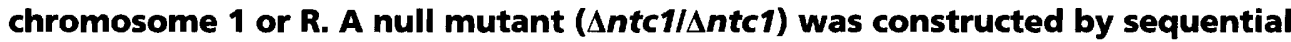
gene disruption. Extracts from mutants homozygous for neutral trehalase deletion had only marginal neutral trehalase activity. Extracts from heterozygous mutants showed intermediate activities between extracts from the wild-type strain and from the homozygous mutants. The null mutant showed no significant differences in pathogenicity as compared to the wildtype strain in a mouse model of systemic candidiasis. This result indicates that the neutral trehalase of $C$. albicans is not a potential target for antifungal drugs.
\end{abstract}

Keywords: neutral trehalase, Candida albicans, gene disruption, pathogenicity

\section{INTRODUCTION}

Trehalases, trehalose-hydrolysing enzymes, have been isolated from many organisms (Hill \& Sussmann, 1963; Killick, 1985; Merdinger et al., 1971; Retief \& Hewitt, 1973; Arguelles \& Gacto, 1985). Fungal trehalases are divided into acid trehalases and neutral trehalases (Thevelein, 1984). Acid trehalases exhibit their maximal activity around $\mathrm{pH} 4 \cdot 5$. They are localized in the vacuole (Mittenbühler \& Holzer, 1988). Neutral trehalases exhibit their maximal activity around $\mathrm{pH} 7 \cdot 0$. They can be activated by phosphorylation and are localized in the cytosol (App \& Holzer, 1989).

The gene encoding the Saccharomyces cerevisiae neutral trehalase (NTH1) was cloned and characterized by Kopp et al. (1993). It has an ORF of 2253 bp (Kopp et al., 1994). The native protein consists of two identical subunits with a molecular mass of $86 \mathrm{kDa}$ (App \& Holzer, 1989; Kopp et al., 1993, 1994).

Abbreviations: 5-FOA, 5-fluoroorotic acid.

The EMBL accession number for the sequence reported in this paper is X95099.
S. cerevisiae neutral trehalase is activated by cyclicAMP-dependent phosphorylation. Dephosphorylation of the active phosphorylated enzyme by alkaline phosphatase is accompanied by $90 \%$ inactivation (App \& Holzer, 1989). The phosphorylated amino acid residues were identified as phosphoserines. The amino acid sequence suggested two possible phosphorylation sites close to the $\mathrm{N}$-terminus.

The predicted amino acid sequence of the NTH1 gene product shows $77 \%$ identity to the amino acid sequence of an ORF, YBR0106, from S. cerevisiae (Wolfe \& Lohan, 1994). In contrast to the NTH1 deletion mutant, a mutant disrupted in the YBR0106 ORF showed no changes in trehalase activity. Disruption experiments showed that trehalose accumulated during heat stress is hydrolysed by neutral trehalase and not by acid trehalase (Mittenbühler \& Holzer, 1988).

Neutral trehalase is of minor importance in humans. Trehalose has not yet been found at a significant level in mammals. The trehalase detected in the brush border membranes of the small intestine is most probably involved in the hydrolysis of ingested trehalose and has 
no essential functions (Forstner et al., 1968). The physiological role of kidney trehalase is still unclear (George \& Kenny, 1973; Kyosseva et al., 1995). It has been suggested that trehalase could be involved in sugar transport in the mammalian kidney (Sacktor, 1968).

Different growth phases (budding, conidiation, germination) of fungi are connected with accumulation or mobilization of trehalose. Trehalose plays a role as a protectant against environmental injuries (Wiemken, 1990) and as a storage carbohydrate (Thevelein, 1984). It accumulates under conditions of restricted growth, during sporulation and upon various stress conditions (heat shock, hyperosmotic shock, dehydration, cold shock). This accumulation correlates with an increase in thermotolerance (Hottiger et al., 1987). Breakdown of storage trehalose is usually one of the main biochemical events during early germination of fungal spores (Thevelein, 1984). Hyphal growth of the phytopathogenic fungus Rhizoctonia solani is connected with the mobilization of trehalose by trehalase. Validamycin A, a potent inhibitor of trehalase, is active against sheath blight of rice plants caused by $R$. solani (Asano et al., 1987).

Although trehalose metabolism has been extensively studied in S. cerevisiae, our knowledge of its physiological significance in the human pathogenic yeast Candida albicans is limited. Trehalases have been isolated from different Candida species. Acid trehalases have been found in C. tropicalis (Luces \& Phaff, 1952) and C. albicans (Arnold \& McLellan, 1975). A neutral trehalase was identified in C. utilis (Arguelles \& Gacto, 1985). This trehalase is similar to the $S$. cerevisiae enzyme activated by cyclic-AMP-dependent phosphorylation and deactivated by phosphatases (Carrillo et al., 1995). For evaluation of neutral trehalase as a target for the screening of antifungal compounds, we cloned and disrupted the C. albicans gene which encodes neutral trehalase, NTC1, and tested the pathogenicity of strains heterozygous and homozygous for ntc1 disruption in a mouse model for systemic candidiasis.

\section{METHODS}

Strains and culture conditions. Escherichia coli XL1-Blue $\left\{\right.$ supE44 hsdR17 recA1 endA1 gyrA46 thi relA1 lac $\mathrm{F}^{\prime}$ [proAB ${ }^{+}$ lac $\left.\left.I^{\mathrm{a}} \mathrm{M} 15 \mathrm{Tn} 10(\mathrm{Tet})\right]\right\}$ (Stratagene) was used for cloning. C. albicans strain BMSY 212, a clinical isolate, was used for cloning of the NTC1 gene. C. albicans CAI-4 (URA3::imm434/URA3::imm434) derived from the wildtype strain SC5314 was used as the parental strain for NTC1 gene disruption. Strain SC5314 was used as wild-type strain in the growth analysis and pathogenicity tests (Fonzi \& Irvine, 1993). Strain 3153a was used for the preparation of a cDNA library in the lambda ZAP II vector (Stratagene) (Swoboda et al., 1993). C. albicans was routinely cultured in YPG medium ( $2 \%$ glucose, $2 \%$ peptone, $1 \%$ yeast extract) at $28^{\circ} \mathrm{C}$. For transformation, C. albicans cells were spread on YNB plates $[0.7 \%$ yeast nitrogen base (Difco Laboratories), $2 \%$ glucose, $2 \%$ Noble agar]. For the neutral trehalase assay, C. albicans cells were grown in YEG medium ( $2 \%$ glucose, $1 \%$ yeast extract). Hyphal formation was induced using three different experimental conditions with shift up in temperature to $37^{\circ} \mathrm{C}$ [addition of $10 \%(\mathrm{v} / \mathrm{v}) \mathrm{N}$-acetylglucosamine to YPG medium, addition of $1 \mathrm{ml}$ serum to YPG medium and shift from $\mathrm{pH} 4.5$ to $\mathrm{pH} 6.5$ in Soll's medium (Soll, 1986)]. Hyphal growth was monitored by light microscopy after $0,45,60,90,120$ and $150 \mathrm{~min}$. To impose heat shock, C. albicans strains (SC5314 and homozygous $n t c 1$ mutant strain) were grown in YPG medium at $28{ }^{\circ} \mathrm{C}$ to mid-exponential growth phase with shaking at 200 r.p.m. Cells were diluted $1: 10(\mathrm{v} / \mathrm{v})$ in fresh YPG medium preheated to 40,45 and $50^{\circ} \mathrm{C}$ and left at this temperature for $10 \mathrm{~min}$. Cells were than returned to $28^{\circ} \mathrm{C}$ and the $\mathrm{OD}_{600}$ was measured at different times up to $60 \mathrm{~min}$. To compare the growth of the homozygous ntc1 mutant strain with the growth of the wild-type strain SC5314, equal numbers of cells from overnight cultures were added to preheated $\left(28^{\circ} \mathrm{C}, 37^{\circ} \mathrm{C}\right.$ and $\left.40^{\circ} \mathrm{C}\right)$ YPG medium. The $\mathrm{OD}_{600}$ was measured at different times up to $60 \mathrm{~min}$. Growth (at $28^{\circ} \mathrm{C}$, $37^{\circ} \mathrm{C}$ and $42^{\circ} \mathrm{C}$ ) and the effect of heat shock $\left(40^{\circ} \mathrm{C}, 45^{\circ} \mathrm{C}\right.$ and $\left.50{ }^{\circ} \mathrm{C}\right)$ were also determined in trehalose medium $(0.7 \%$ yeast nitrogen base, $2 \%$ trehalose).

Construction of a probe for the NTC1 gene. Oligonucleotide primers $1\left(5^{\prime}\right.$ CCATATGCTGTCCAGGTGGTAGATT $\left.3^{\prime}\right)$ and $2\left(5^{\prime}\right.$ GGTGGTTGTGATCTACATAAATAATA $\left.3^{\prime}\right)$ were derived using the trehalase consensus sequences of the S. cerevisiae NTH1 gene (Kopp et al., 1993, 1994), the E. coli tre A gene (Gutierrez et al., 1989) and the Tre gene from rabbit small intestine (Ruf et al., 1990) (see Fig. 2). The sequences of the primers were adapted to the codon usage in C. albicans (Lloyd \& Sharp, 1992) because the DNA of C. albicans is A/T-rich (third position of triplets mostly contains an A or T). Using primers 1 and 2, a 178 bp fragment of the NTC1 gene (NTCPS) was amplified by PCR using C. albicans genomic DNA and cloned into the pCR-Script Amp SK(+) cloning vector (Stratagene). The nucleotide sequences were determined by the dideoxy chain-termination method with the $\mathrm{T} 7$ standard primer using the Sequenase version 2.0 kit (United States Biochemical) (Sanger et al., 1977).

PCR. PCR amplification reactions were carried out in a $100 \mu \mathrm{l}$ reaction volume containing $10 \mathrm{mM}$ Tris $/ \mathrm{HCl} \mathrm{pH} 8.3,1.5 \mathrm{mM}$ $\mathrm{MgCl}_{2}, 50 \mathrm{mM} \mathrm{KCl}, 0.2 \mathrm{mM} \mathrm{dNTP}$ and $0.2 \mu \mathrm{M}$ of each primer. The reaction was started by addition of 1 unit Taq polymerase (Boehringer) and the samples were overlaid with mineral oil. Thirty cycles, consisting of a $30 \mathrm{~s}$ incubation at $96^{\circ} \mathrm{C}, 1 \mathrm{~min}$ at $42^{\circ} \mathrm{C}$ and $2 \mathrm{~min}$ at $72^{\circ} \mathrm{C}$, were performed using an Omn-E Hybaid thermal cycler.

Cloning and sequence analysis of the NTC1 gene. Chromosomal DNA from C. albicans strain BMSY 212 was fractionated and probed with NTCPS. Hybridizing fragments were isolated and cloned into plasmid pUC18. By screening this size-selected library with NTCPS a single clone was obtained. Furthermore, using the same probe we isolated three cDNA clones from a ZAP II expression library. The nucleotide sequences were determined by the dideoxy chain-termination method with synthetic oligonucleotide primers using the Sequenase version 2.0 kit (United States Biochemical) (Sanger et al., 1977). All other recombinant DNA procedures were carried out according to standard protocols (Sambrook et al., 1989). Alignments were done by the GCG software package (Genetics Computer Group, Madison, WI, USA).

Construction of plasmid pNR1. We amplified the $5^{\prime}$ region of NTC1 by PCR using chromosomal DNA of C. albicans strain BMSY 212 and primers 3 and 4 (primer 3, $5^{\prime}$ GCGAGCTCCAGCAATTCATTCTGATTCTGAGG 3', position +314 to +337 ; primer 4, 5' GCGGTACCGCCAGTATCTTCAATGGTAATTTG $3^{\prime}$, position +765 to +742 ; underlined sequences are complementary to the 
(a)

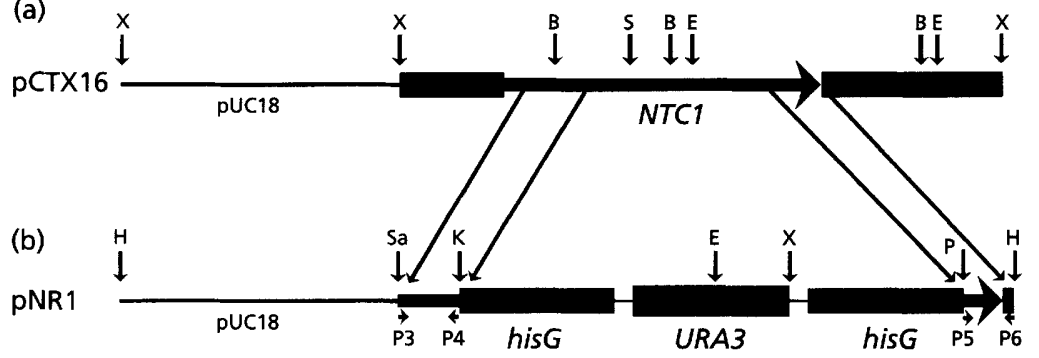

Fig. 1. Restriction maps of plasmids pCTX16 and pNR1. (a) The NTC1 gene (arrow, coding region; boxes, non-coding regions) was cloned into pUC18, resulting in PCTX16. (b) The 5' and 3' regions of NTC1 obtained by PCR were cloned in front of or behind the hisG-URA3-hisG cassette $(4 \mathrm{~kb})$ in the disruption vector PMB-7. Arrows (P3, P4, P5, $P 6)$ indicate the primers used. $X, X$ bal; $B$, BamHI; S, Sall; E, EcoRI; K, Kpnl; P, Pstl; H, HindllI; Sa, Sacl. genomic sequence of the NTC1 gene). The resulting $468 \mathrm{bp}$ fragment was digested with $S a c \mathrm{I} / K p n \mathrm{I}$ and cloned in front of the hisG-URA3-hisG cassette (4 kb) of pMB-7 (Fonzi \& Irvine, 1993) to give pMB-7/1. Primer 5 (5' GCCTGCAGCAAAGGGAGCAGTACCTCATAGAG 3', position +2507 to +2530$)$ and primer $6\left(5^{\prime}\right.$ GCAAGCTTAAACTCCAAACTCAAAGGAAGGACT 3 ', position -49 to -26 downstream of the stop codon) were used to amplify the 3 ' end of NTC1. The resulting $284 \mathrm{bp}$ fragment was digested with HindIII/PstI and cloned into pMB-7/1. The resulting plasmid, pNR1, containing the hisG-URA3-his G cassette flanked by the $5^{\prime}$ and $3^{\prime}$ regions of the NTC1 gene was used for gene disruption (Fig. 1b).

\section{Transformation of $C$. albicans and selection of heterozygous} and homozygous neutral trehalase mutants. Midexponential-phase yeast cells from a $150 \mathrm{ml}$ YPG culture of $C$. albicans $\mathrm{CAI}-4$ and the trehalase heterozygous mutant strain CAI-4 NTC1/ $\Delta n t c 1::$ is G (for the second disruption) were harvested by centrifugation and washed three times with $1 \mathrm{M}$ sorbitol, $10 \mathrm{mM}$ Tris/ $\mathrm{HCl} \mathrm{pH} 8 \cdot 0,1 \mathrm{mM}$ EDTA at room temperature. The cells were incubated for $10 \mathrm{~min}$ in $10 \mathrm{ml} 1 \mathrm{M}$ sorbitol, $10 \mathrm{mM}$ Tris/ $\mathrm{HCl} \mathrm{pH}$ 8.0,50 mM DDT, 1 mM EDTA at room temperature. After washing with $1 \mathrm{M}$ sorbitol, $0 \cdot 1 \mathrm{M}$ $\mathrm{Na}$ citrate $\mathrm{pH} 5 \cdot 8,10 \mathrm{mM}$ EDTA, the cells were resuspended in $10 \mathrm{ml} 1 \mathrm{M}$ sorbitol, $0.1 \mathrm{M} \mathrm{Na}$ citrate, $\mathrm{pH} 5.8,10 \mathrm{mM}$ EDTA, $10 \mu \mathrm{g}$ Zymolyase $\mathrm{ml}^{-1}$ and shaken for $60 \mathrm{~min}$ at $30^{\circ} \mathrm{C}$. Spheroplasts were washed three times with $1 \mathrm{M}$ sorbitol, $10 \mathrm{mM}$ Tris $/ \mathrm{HCl} \mathrm{pH} 8.0,1 \mathrm{mM}$ EDTA at $4{ }^{\circ} \mathrm{C}$ and resuspended in $0.5-1.0 \mathrm{ml} 1 \mathrm{M}$ sorbitol, $10 \mathrm{mM} \mathrm{Tris} / \mathrm{HCl}$ pH $8 \cdot 0,1 \mathrm{mM}$ EDTA. In a $1.5 \mathrm{ml}$ tube, $100 \mu \mathrm{l}$ spheroplast suspension was gently mixed with $10 \mu \mathrm{g}$ plasmid pNR1 digested with SacI and HindIII. After incubation for $10 \mathrm{~min}$ on ice, electroporation was performed with ice-cold $0.2 \mathrm{~cm}$ electrode gap cuvettes at $1.5 \mathrm{kV}$ voltage, $100 \Omega$ resistance and $25 \mu \mathrm{F}$ capacity using a Gene Pulse apparatus (Bio-Rad). The electroporated cell suspension was mixed with $0.5 \mathrm{ml} 1 \mathrm{M}$ sorbitol, $1 \%$ peptone, $2 \%$ glucose and incubated for $60 \mathrm{~min}$ at $30{ }^{\circ} \mathrm{C}$. Aliquots of $100 \mu \mathrm{l}$ were spread on YNB plates supplemented with $1 \mathrm{M}$ sorbitol (Swoboda et al., 1995). Uridinepositive colonies could be detected after $3-4$ days incubation at $30^{\circ} \mathrm{C}$. The disruption of trehalase genes was verified by Southern analysis and PCR.

Selection of Ura- auxotrophs. This was done on medium containing 5-fluoroorotic acid (5-FOA) (Boeke et al., 1984). Prior to selection the strains were plated on YPG agar and incubated for $48 \mathrm{~h}$ at $30^{\circ} \mathrm{C}$. Individual colonies were suspended in $200 \mu \mathrm{H} \mathrm{H} \mathrm{H}_{2} \mathrm{O}$. Aliquots of $50 \mu \mathrm{l}$ were spread on YNB plates with uridine $\left(25 \mu \mathrm{g} \mathrm{ml}^{-1}\right)$ and 5-FOA $\left(1 \mathrm{mg} \mathrm{ml}^{-1}\right)$. Ura cells grew after $3-4$ days incubation at $30^{\circ} \mathrm{C}$.

Southern blot analysis. Southern blot analysis of genomic DNA from C. albicans strain BMSY 212, mutant strains and the chromosomes of $C$. albicans strain BMSY 212 was performed according to standard procedures (Sambrook et al., 1989).

Electrophoretic karyotyping. Separation of chromosomes in a CHEF (Bio-Rad) apparatus was performed with a running time of $24 \mathrm{~h}$ at $150 \mathrm{~V}$ with a pulse time of $120 \mathrm{~s}$, followed by $40 \mathrm{~h}$ at $150 \mathrm{~V}$ with a pulse time of $240 \mathrm{~s}$. The gel was run using a $120^{\circ}$ rotation angle at a temperature of $10^{\circ} \mathrm{C}$.

Preparation of total RNA from C. albicans. Late-exponentialphase yeast cells from a $150 \mathrm{ml}$ YPG culture were harvested by centrifugation, resuspended in $10 \mathrm{ml} 50 \mathrm{mM} \mathrm{Na}$ acetate, $10 \mathrm{mM}$ EDTA pH 5.3, $10 \mathrm{ml}$ phenol, $100 \mu \mathrm{l} 10 \%$ SDS and incubated twice for $5 \mathrm{~min}$ at $65^{\circ} \mathrm{C}$ followed by $5 \mathrm{~min}$ in liquid nitrogen. After centrifugation, the aqueous phase was extracted with phenol and with phenol/chloroform $(1: 1$, $\mathrm{v} / \mathrm{v})$. After ethanol precipitation the RNA was dissolved in $80 \%$ ethanol and quantified on the basis of $A_{260}$.

Northern blot analysis. RNA samples were separated in formaldehyde gels containing $1 \%$ agarose. The RNA was blotted onto Hybond nylon membranes (Amersham). Membranes were hybridized and washed by standard techniques (Sambrook et al., 1989).

Primer extension analysis. Two hundred nanograms $[\gamma$ $\left.\mathrm{P}^{32}\right]$ ATP end-labelled primer (PEXIRD) $5^{\prime}$ GCAACATCAAATGGGTCATCATCACTTGATGTAG $3^{\prime}$ (position +65 to +32 of NTC1) was precipitated with $200 \mu$ g total RNA prepared from $C$. albicans strain BMSY 212. One hundred microlitres annealing buffer $(0 \cdot 15 \mathrm{M} \mathrm{KCl}, 10 \mathrm{mM}$ Tris $/ \mathrm{HCl}$ $\mathrm{pH} 8.3)$ was added and the sample was denatured and annealed $\left(15 \mathrm{~min}\right.$ at $90^{\circ} \mathrm{C}, 90 \mathrm{~min}$ at $\left.30^{\circ} \mathrm{C}\right)$. After precipitation primer extension was performed with 40 units of avian myeloblastosis virus reverse transcriptase (Boeringer Mannheim), $1 \mu \mathrm{l}$ rRNasin (Boeringer Mannheim), $1 \mathrm{mM}$ dATP, $1 \mathrm{mM}$ dTTP, $1 \mathrm{mM}$ dCTP, $1 \mathrm{mM}$ dGTP, $50 \mathrm{mM}$

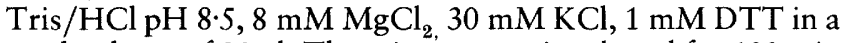
total volume of $20 \mu \mathrm{l}$. The mixture was incubated for $120 \mathrm{~min}$ at $42{ }^{\circ} \mathrm{C}$. Two microlitres $0.5 \mathrm{M} \mathrm{NaOH}$ was added and the mixture incubated for $15 \mathrm{~min}$ at $65^{\circ} \mathrm{C}$. After addition of $80 \mu \mathrm{l}$ $10 \mathrm{mM}$ Tris $/ \mathrm{HCl} \mathrm{pH} \mathrm{8.0,1} \mathrm{mM} \mathrm{EDTA} \mathrm{and} 10 \mu \mathrm{l} 3 \mathrm{M} \mathrm{Na}$ acetate $\mathrm{pH} 5 \cdot 3$, the sample was precipitated and resuspended in $8 \mu$ l loading buffer $(95 \%$ formamide, $20 \mathrm{mM} \mathrm{EDTA}, 0.05 \%$ bromphenol blue, $0.05 \%$ xylene cyanol). At the same time, the end-labelled primer PEXIRD was used to prime a DNA sequencing reaction on the genomic NTC 1 clone by using the Sequenase version $2.0 \mathrm{kit}$ (United States Biochemical) (Sanger et al., 1977). The primer extension reaction, sequencing reactions and the end-labelled primer were analysed on a $6 \%$ polyacrylamide/urea gel.

Partial purification of neutral trehalase. C. albicans cells grown at $30^{\circ} \mathrm{C}$ in YEG medium were homogenized (BeadBeater, BioSpec Products, Bartlesville, USA) with glass beads in extraction buffer $(50 \mathrm{mM}$ imidazole- $\mathrm{HCl} \mathrm{pH} 7 \cdot 0,1 \mathrm{mM}$ PMSF and $15 \mu \mathrm{g}$ Pepstatin $\mathrm{ml}^{-1}$ ). After centrifugation (30 min, 
1

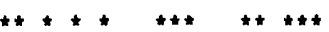

$\star \star \star \star \star * *$ *

\#* *

Tre-C ....... MFTKNHRRMS STSSDDDPFD VAEKYYG........EERK KKLNRVRTES AFESTKYGAG PISPLRPTYE PPPVIKETSE PLSSSSSTSS

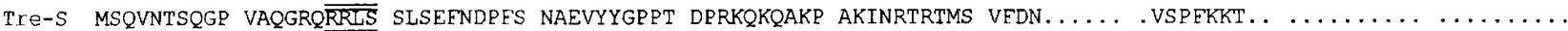

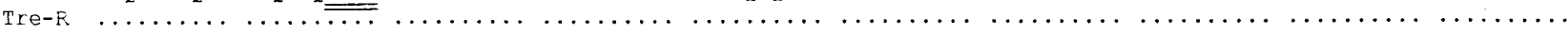

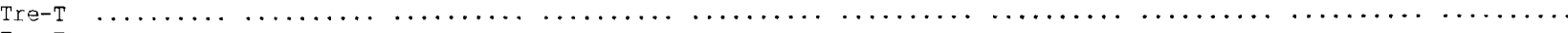

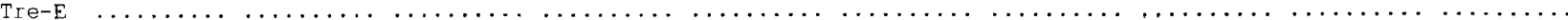

101

*

Tre-c

Tre-s

Tre-R

Tre-T

Tre-

PPTLTPQTSQ VQFNLGVGKT KNGSAIHSDS EEEEEDEDPVS NTKKGEADE KDPFDTTDSK LENENSTPSS ITGKEIIPHP TGERGSSEES AIRRKPSIIP

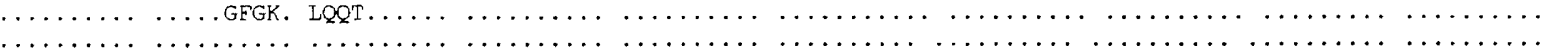

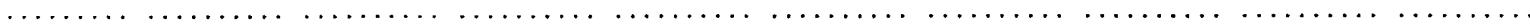
201 $* * * *$

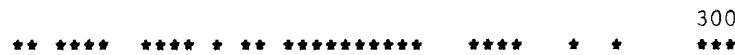

IYHDNISOES VIRNANTPTT YNREKEHLRR GSLDESTFIR PKKYYINDVQ ..GTLRELLA NEDTDNNCQI TIEDTGPKVI RLGTAN...S LGINQSSIRG

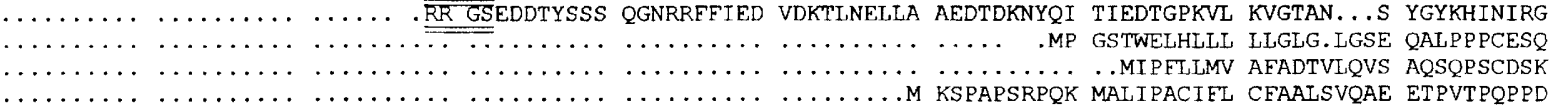

301

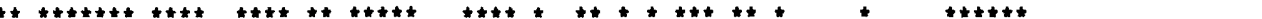

TYRLSNILQE LTIASRYGR QIVLDEARLS ENPVDRMKRL ISTSEWNNLT RIITKENIVD MAKDTKIKES WIDDQGKLHE NQESHRITVP YNRKDQYEFE TYMLSNLLE LTIAKSFGRH QIFLDEARIN ENPVNRISRL INTQEWNSLT RRVDLNNVGE IAKDTKIDTP ........ GAKNPRIIVP YDCPEQYEFY IYCHGETIHO VQMARLYPDD KOFVD.MPLS TAPDQVLQSF ...AELAATYN NTVPREQLEK FVQE...........HFQA VGQELESWTP GDWKESPQFI VYCQGKLLHV VEMSRI INDS KTFVE.LKMI NDEQTTLENF ..DNFLRDTN HKRTRADLMK FVSD..... . . . . NFKQ . ENEFESWTP TDFTDNPTLL 401

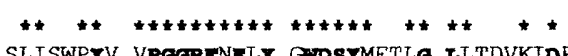

Tre-c

Tre-s

Tre-R

Tre-T

Tre-E

\section{1}

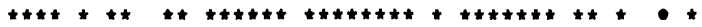

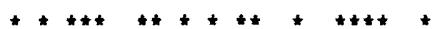

IQLDVQYLPQ KIDADYIKSI NKKPGLLSIA TRPDPQAPDS G.SLISWPTV VPGGRTILY GWSTMEILG LLTDVKIDPS GNPRNLRHLE VQASQMH. PS LKLEVEYLPK KITAEYVKSV NDTPGLLALA MEEHENPSTG EKTLIGYPYA VPGGRTNLI GWDSYM QKISDPKLRA WAEQLHLLWK KLGKKIKPEV LSQPERESLI YSQH. . . . . . . . P SRIEDKTIRQ FAQDLVKIWP TLARKVKKEV LDYPEHYSLL PVDN . . . . . . . . GFI I I GGRTTEFT YWDSTWIVEG ILLSDMHET. . . . . . .

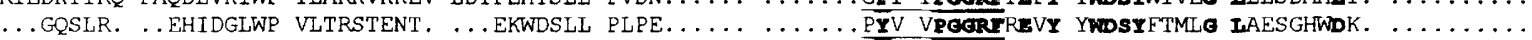

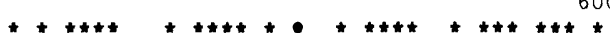

Tre-C LARGAENII YEIHHYGKIL NANRSYYLGR SOPPILTDMA LRIFNKTIE. . VTPELMDE AIDFLKRATL AAIKEYETIW CAHPRLDDKT GISCYHPEGK Tre-S VARGNEHII FEINHYOKIL TANRSYYLCR SQRPIITEMA LVVFKK.... . LGGRSNPD AVDLLKRAFQ ASIKEYKTVW TASPRLDPET GLSRYHPNGL

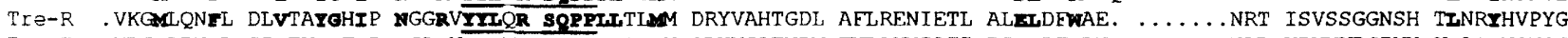
Tre-T .VRGQDNTL SIVEKTGFIP NGARV IIINR SOPEILTLMV SLYVSATNDM EWLAKNIRTI DTELRFWN. ...... NRL VDVVKDGIVY KIAQYNSNSG TIE-E . VADMVANA HEIDTYGHIP NGNRSYYISR SQPEFTAIMV ELLAQHEGDA A.LKQYLPQM QKEYAYWMD VENLQAGQQE KRVVKLQDGT IINRYWDDRD

601

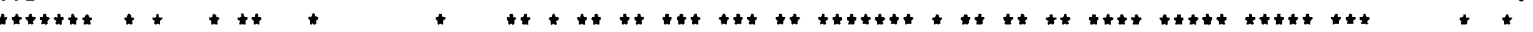

Tre-C GIPPETEPTH FNALLKPYLA KYNDIDQLDF IEKYNSGEIK EPELDEYFLH DRAVRESGHD TSYRLEGKCA YLATVDLNST LYKYENDIAF ILQSEFNDNL Tre-S GIPPETESDH FDTVLLPYAS K. HGVTLDEF KQLYNDGKIK EPKLDEFFLH DRGVRESGHD TTYRFEGVCA YLATIDINSI LYKYEIDIAD EIKEFCDDKY Tre-R GPRPESYSKD TELA.... .HT LPEG. SWETL WAELKAGAES GWDFSSRWLV G..SPNPDSL GSIRTSK. . . LVPVDINAF LCOAEELLSG EYSRLGNE.

TIE-T SPRPESYYED VTTA.... .SV FSDERDKAEL YMDLKSAAES GWDFSSRWIV DEYGGTRGNL SALHTRR... . IIPVDLNAF LCQAFQKLSE FYQTLGDY..

Tre-E TPRPESWVED IATA.....KS NPN. RPATEI YRDLRSAAAS GWDFSSRWM. ... DNPQQL NTLRTTS... . IVPVDINSI MEKMEKILAR ASKAAGDN..

701

800

QDPYDDNNSN KIHSSKI\%LE RSHQRKLNVD KYLWNEQDGI YYDYNVKLQQ QTNYESATT WPIYAKLASS NQAAKLIDQS LHKEEEHGGL VAGTLKSRGE re-S EDPLD....H SITTSAMAKE MAKIROEKIT KYMTDDESGF FEDYNTKIKH RTSYESATTT WALWAGLATK EOAOKMVEKA LPKLEMLGGL AACTERSRGP Tre-R ........ . SQATKYRN LRAQRIAALT ALLWDEDKGA WEDYDLENQK KNHEFYPSNI TPLWAGCFSD PA... IADKA LQYLQDSQIL ... NHRHGIP Tre-T . . . . . . PNATWWSK LVKIWOHSIE MVHYNRDDGI WYDWDNELSQ HRRMFEPSNI APIWSETEDS RNAEILGEMA AEYFITQNMM ... DYHGGIP Tre-E .......... AMANQYET LANARQKGIE KYLWNDQQGW YADYDLKSHK VRNQLTAAAI FPIYYNAAAK DRANKMATAT KTHLLQP... ..... GGLN

801

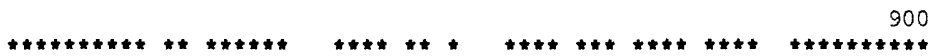

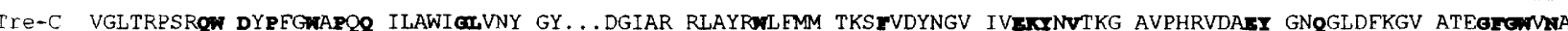

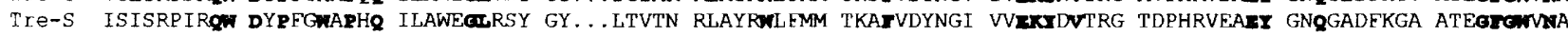

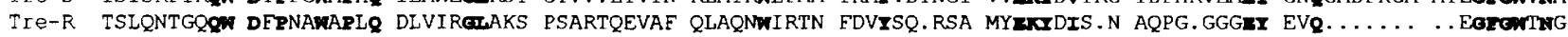

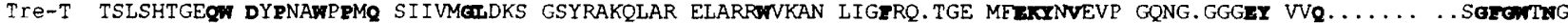

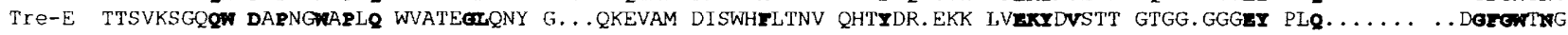

\begin{tabular}{|c|c|c|c|c|c|}
\hline & 01 & 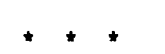 & 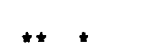 & * & \\
\hline & SYVEGITELN & LYAQRALGSL & TPPEIFLRNM & HPEQRKQYK & \\
\hline & ILGLKYMN & SYERREIGAC & IPPISFESSL & RNEYGL & \\
\hline & - VAIMLLD & RYGDRLSSGT & QLALLEPHCL & AAALLLSFLT & \\
\hline & vvr & & & & \\
\hline$-E$ & . VTLKMLD & CPKEQPCD & $T R$ & TKE & \\
\hline
\end{tabular}

Fig. 2. Multiple alignment for maximal amino acid similarity of neutral trehalases from $C$. albicans (Tre-C), S. cerevisiae (Tre-S), rabbit (Tre-R), the insect Tenebrio molitor (Tre-T) and E. coli (Tre-E). Amino acids are shown in single-letter code. Similar residues are indicated by bold letters. Similar amino acids of neutral trehalases from C. albicans and S. cerevisiae are indicated by asterisks. The proposed phosphorylation sites are doubly underlined. The sequences used for the derivation of PCR primers 1 and 2 are underlined. 
$43000 \mathrm{~g}$ ), crude extract was obtained from the supernatant (total protein concentration $10-20 \mathrm{mg} \mathrm{ml}^{-1}$ ). Neutral trehalase in the crude extract was activated by addition of $1 / 5 \mathrm{vol}$. phosphorylation solution (1 mM ATP, $10 \mu \mathrm{M}$ cAMP, $10 \mathrm{mM}$ $\mathrm{MgSO}_{4}, 50 \mathrm{mM} \mathrm{NaF}, 5 \mathrm{mM}$ theophylline in extraction buffer) and incubated for $10 \mathrm{~min}$ at $30^{\circ} \mathrm{C}$. Phosphorylation was stopped by transfer to ice. Activated crude extract aliquots containing $25 \mathrm{mg}$ total protein were separated by anion exchange chromatography on a DEAE-cellulose column (Whatman DE-52, $1.6 \mathrm{~cm} \times 10 \mathrm{~cm}, 50 \mathrm{mM}$ imidazole/ $\mathrm{HCl}$ buffer $/ \mathrm{NaCl}$ gradient). Neutral trehalase activity eluted at about $250 \mathrm{mM} \mathrm{NaCl}$, whereas acid trehalase activity was found in the flowthrough. Fractions containing neutral trehalase activity were pooled as partially purified neutral trehalase.

Enzyme assay. Enzymic activity of neutral trehalase was tested at $37^{\circ} \mathrm{C}$. The reaction mixtures contained $100 \mathrm{mM}$ trehalose, $10 \mathrm{mM} \mathrm{MnCl}$, $50 \mathrm{mM}$ MES pH 6 and $100 \mu \mathrm{l}$ partially purified neutral trehalase in a total volume of $400 \mu \mathrm{l}$. Reactions were stopped by boiling for $5 \mathrm{~min}$ after $30-60 \mathrm{~min}$. The concentration of the released glucose was determined by enzymic Trinder assay (Sigma). Trehalase activities were calculated in units ( $\mathrm{mg}$ total protein) ${ }^{-1}$ in crude extracts (1 unit catalyses the hydrolysis of $1 \mu \mathrm{mol}$ trehalose $\mathrm{min}^{-1}$ and the release of $2 \mu \mathrm{mol}$ glucose $\mathrm{min}^{-1}$ ). Values given are means \pm standard deviations of at least two measurements.

Pathogenicity assays. The mouse candidiasis model described by Plempel (1984) was used to test the pathogenicity of $C$. albicans mutants. Briefly, wild-type or mutant strains were grown for $24 \mathrm{~h}$ at $28^{\circ} \mathrm{C}$ in YNB medium. Mice $(n=20)(8-$ week-old, male, strain CFW1; Halan-Winkelmann) were infected by injection of $10^{6}$ cells in $0 \cdot 2 \mathrm{ml}$ PBS into the caudal vein. Survival was monitored for $13 \mathrm{~d}$. Survival curves were calculated according to the Kaplan-Meier method using the Prism program (GraphPad Software, San Diego, USA) and compared using the log-rank test. A $P$ value $\leqslant 0.05$ was considered as significant.

\section{RESULTS}

\section{Cloning of the $C$. albicans gene encoding the neutral trehalase}

Using primers 1 and 2 a $178 \mathrm{bp}$ fragment from $C$. albicans strain BMSY 212 genomic DNA was amplified by PCR. The PCR product was cloned into the pCRScript Amp $\mathrm{SK}(+)$ cloning vector. The nucleotide sequences were determined with the $\mathrm{T} 7$ standard primer.

Sequence analysis of the cloned PCR product showed $75 \%$ identity to the neutral trehalase gene NTH1 of $S$. cerevisiae. The PCR product (NTCPS) was used as probe in Southern analysis of C. albicans strain BMSY 212 genomic DNA digested with $\mathrm{Xba \textrm {I }}$. The probe hybridized with a fragment of $4.7 \mathrm{~kb}$. Fragments of approximately $4.7 \mathrm{~kb}$ were cloned into plasmid pUC18. After colony hybridization with the NTCPS probe, plasmid pCTX16 was isolated (Fig. 1a).

\section{Sequence analysis of the NTC1 gene}

The $4.7 \mathrm{~kb}$ insert of pCTX16 contained one ORF of $2724 \mathrm{bp}$. This ORF encodes a polypeptide consisting of 907 amino acids with a calculated molecular mass of
$104 \mathrm{kDa}$. At position +2061 of NTC1 the nucleotide A in the genomic clone (strain BMSY 212) is replaced by the nucleotide $\mathrm{C}$ in the cDNA clones (strain 3153a). The triplet AAA in the genomic clone codes for lysine, whereas AAC in the CDNA clone codes for aspartic acid.

Amino acid sequence comparison using the program GAP from the GCG software package revealed a $57 \%$ overall identity between the neutral trehalases Nth1p from $S$. cerevisiae and $\mathrm{Ntc1p}$ from C. albicans, supporting the assumption that the C. albicans neutral trehalase gene had been isolated. The C. albicans neutral trehalase is 156 amino acids longer than the $S$. cerevisiae enzyme. Most of the additional amino acids are localized in the N-terminus (Fig. 2).

The deduced amino acid sequence showed two possible cAMP-dependent phosphorylation sites: Arg/Arg/ Met/Ser at position 7 and Arg/Arg/Leu/Ser at position 210 (Fig. 2) (Rittenhouse et al., 1986).

Three independent cDNA clones were isolated from the ZAP II C. albicans 3153a cDNA library (Swoboda et al., $1995)$ by plaque hybridization with the ${ }^{32} \mathrm{P}$-labelled probe NTCPS. The $5^{\prime}$ and $3^{\prime}$ ends of the three inserts were sequenced. No full-length cDNA was isolated. All three clones have an identical 196 nucleotide sequence between the stop codon and the poly(A) cleavage site.

\section{Mapping the NTC1 gene transcription unit}

The transcriptional start site on the NTC1 gene was mapped by primer extension. One transcription start site was observed 130 bases upstream from the ATG start codon of the NTC1 gene. A TATA-like sequence exists 19 bases upstream from the transcription start site. The mRNA poly(A) cleavage site was determined by sequencing the $3^{\prime}$ end of three independent cDNA clones. The nucleotide $T$ at position -196 downstream from the stop codon is the last transcribed nucleotide of the chromosomal sequence since the following nucleotide on chromosomal DNA is a $\mathrm{T}$ and not an A from the poly $(A)$ tail as in the cDNA clones.

\section{Transcription analysis and chromosomal localization of the NTC1 gene}

Northern analysis was performed with total RNA from C. albicans strain BMSY 212 using the internal $1.3 \mathrm{~kb}$ BamHI fragment of the NTC1 gene as probe. A single band of about $3 \cdot 2 \mathrm{~kb}$ was detected (Fig. $3 \mathrm{a}$ ).

Chromosomes from C. albicans strain BMSY 212 were separated by PFGE. Southern analysis showed that the $1.3 \mathrm{~kb} \mathrm{BamHI}$ fragment of NTC1 hybridized with the upper chromosome band (Fig. 3b), which consists of chromosome R comigrating with chromosome 1 (Barton 
(a)

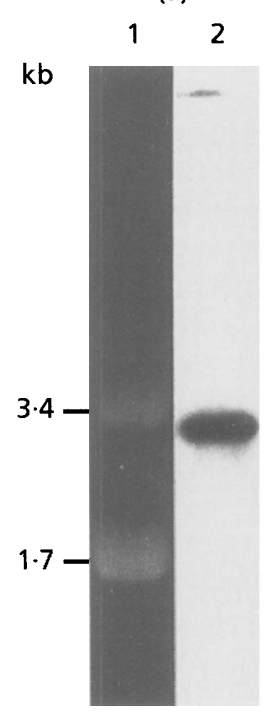

(b)

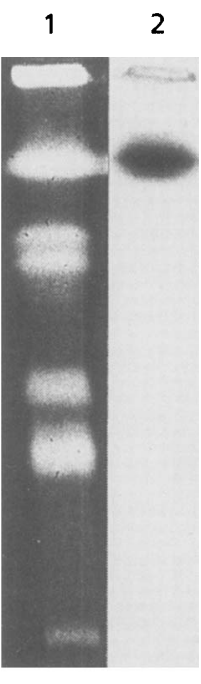

(a)

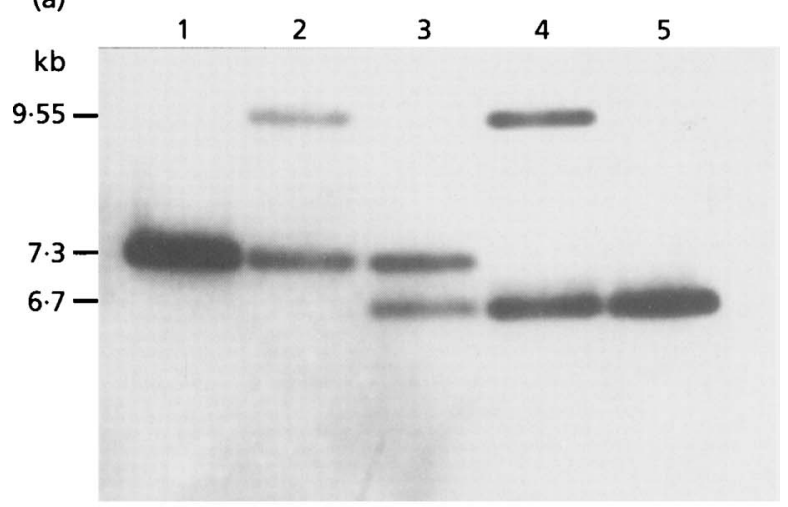

(b)

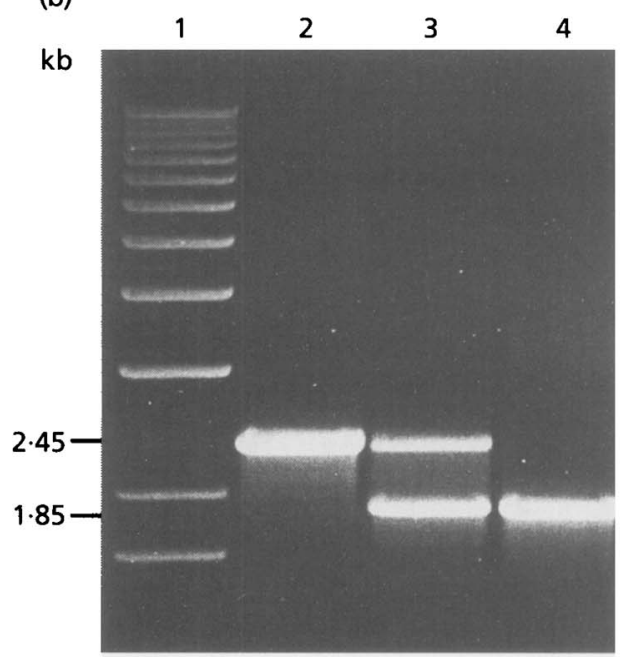

\& Scherer, 1993). It is not possible to separate these two chromosomes by PFGE. The data of the Southern analysis (Figs 3b, 4a) show that the NTC1 gene is a single-copy gene.

\section{Disruption of the NTC1 gene}

C. albicans CAI-4 was transformed with the hisGURA3-his G cassette flanked by $5^{\prime}$ and $3^{\prime}$ NTC1 gene sequences obtained by digestion of pNR1 with SacI/HindIII (Fig. 1b). DNA from a representative Ura ${ }^{+}$ colony was isolated and digested with HindIII. Southern analysis with the ${ }^{32} \mathrm{P}$-labelled $4.7 \mathrm{~kb} \mathrm{XbaI}$ insert of plasmid pCTX16 showed two hybridizing fragments (Fig. $4 \mathrm{a}$, lane 2). One hybridization band is identical to the $7.3 \mathrm{~kb}$ HindIII band of the parental strain CAI-4 in lane 1 . The size of the second hybridizing band of $9.55 \mathrm{~kb}$ is consistent with the replacement of $64 \%$ of the NTC1 gene by the hisG-URA3-hisG cassette.

The disruption of the second trehalase allele required as a first step the loss of the selectable marker gene URA3. Selection of $\mathrm{Ura}^{-}$segregants on 5-FOA plates gave approximately $10^{3}$ C. albicans CAI-4 NTC1/ $\Delta$ ntc1:: bisG Ura ${ }^{-}$colonies. Southern analysis of DNA from a representative colony showed two bands (Fig. 4a, lane 3). One hybridizing band is identical to the $7 \cdot 3 \mathrm{~kb}$ band of the parental strain in lane 1 . The size of
Fig. 4. Sequential disruption of the NTC1 gene. (a) Southern blots of Hindlll-digested chromosomal DNA of the following $C$. albicans strains were hybridized with a $\left[\alpha-{ }^{32} \mathrm{P}\right] \mathrm{dCTP}$-labelled $4.7 \mathrm{~kb}$ Xbal insert of plasmid pCTX16: CAl-4 (parental strain, lane 1), CAl-4 NTC1/Dntc1:: hisG-URA3-hisG (heterozygous strain, lane 2), CAl-4 NTC1/Antc1::hisG (heterozygous strain, lane 3), CAl-4 Antc1::hisG/Antc1::hisG-URA3-hisG (homozygous strain, lane 4) and CAI-4 $\Delta$ tc1::hisG/Dntc1::hisG (homozygous strain, lane 5). (b) Confirmation of NTC1 disruption by PCR. PCR was carried out with primers 3 and 6 (Fig. 1b) and chromosomal DNA from C. albicans CAl-4 (parental strain, lane 2), CAl-4 NTC1/ $\Delta$ ntc1:: hisG (heterozygous

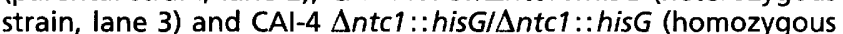
strain, lane 4). Lane 1 contains molecular mass standards ( $1 \mathrm{~kb}$ ladder, Gibco-BRL).

the second band of $6.7 \mathrm{~kb}$ is consistent with the loss of the URA3 gene and one copy of his $G$ from the bisG-URA3-bisG cassette.

The gene replacement was repeated to disrupt the second allele of the NTC1 gene in C. albicans CAI-4, heterozygous for NTC1 gene disruption. Five presumably

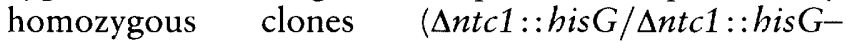
URA3-hisG) were obtained. Southern analysis of chromosomal DNA from a representative clone is shown in Fig. 4a, lane 4. One hybridizing band is identical to the $6.7 \mathrm{~kb}$ band of C. albicans CAI-4 
NTC1/ 1 ntc1::hisG in lane 3. The second band is identical to the $9.55 \mathrm{~kb}$ band of C. albicans CAI-4

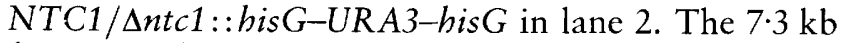
fragment of the parental strain CAI-4 disappeared (see lane 1).

After the second 5-FOA selection one of the $\mathrm{Ura}^{-}$ segregants ( $\Delta n t c 1::$ his $G / \Delta n t c 1::$ is $G$ ) only showed the $6.7 \mathrm{~kb}$ band in Southern analysis (Fig. 4a, lane 5).

These results were confirmed by PCR with primers 3 and 6 (Fig. 1b). Amplification with chromosomal DNA of the parental strain C. albicans CAI-4 resulted in a $2.45 \mathrm{~kb}$ product that represents a fragment of the wildtype NTC1 gene (Fig. 4b, lane 2). PCR with DNA of

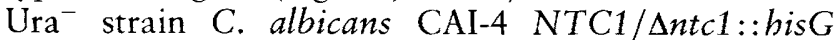
(heterozygous for neutral trehalase mutation) resulted in a $2.45 \mathrm{~kb}$ product identical to the product in lane 2 and a $1.85 \mathrm{~kb}$ product consistent with the replacement of $64 \%$ of the NTC1 gene by one copy of hisG (lane 3 ). PCR with DNA of $\mathrm{Ura}^{-}$strain C. albicans CAI-4 $\Delta n t c 1:: h i s G / \Delta n t c 1:: h i s G$ (homozygous for neutral trehalase mutation) showed only the $1.85 \mathrm{~kb}$ PCR product (lane 4).

\section{Characterization of the mutant strains}

The growth rates of the wild-type strain SC5314 and the homozygous mutant strain were identical at $28^{\circ} \mathrm{C}$, $37^{\circ} \mathrm{C}$ and $42^{\circ} \mathrm{C}$ and after heat shock at $40^{\circ} \mathrm{C}, 45^{\circ} \mathrm{C}$ and $50^{\circ} \mathrm{C}$ in YPG medium. The heterozygous mutant strain grew poorly after heat shock at $50^{\circ} \mathrm{C}$.

In trehalose medium, the growth and the cell number in stationary phase of the homozygous mutant strain were slightly reduced compared with the wild-type strain at $28^{\circ} \mathrm{C}, 37^{\circ} \mathrm{C}$ and $42^{\circ} \mathrm{C}$ and after heat shock at $40^{\circ} \mathrm{C}$, $45^{\circ} \mathrm{C}$ and $50^{\circ} \mathrm{C}$.

Because the hyphal growth of the phytopathogenic fungus $R$. solani is connected with the mobilization of trehalose by trehalase, we estimated the level of NTC1 transcription in yeast and hyphal growing cells, but Northern analysis showed no differences of the NTC1 mRNA level.

Hyphal growth of the homozygous mutant strain after addition of $\mathrm{N}$-acetylglucosamine or serum was delayed (by approximately $30 \mathrm{~min}$ ) compared with the wild-type strain SC5314, but after $2 \mathrm{~h}$ no differences were observed. Hyphal growth of the homozygous mutant and the wild-type strain after shift from $\mathrm{pH} 4.5$ to pH 6.5 in Soll's medium was identical.

\section{Neutral trehalase activity in mutant strains of C. albicans}

Crude extracts of C. albicans CAI-4 and trehalase

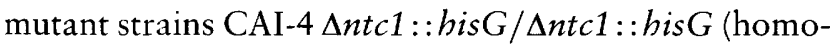
zygous for neutral trehalase mutation) and CAI-4 NTC1/ $\triangle$ ntc1:: hisG (heterozygous for neutral trehalase mutation) were activated by cAMP-dependent phos-

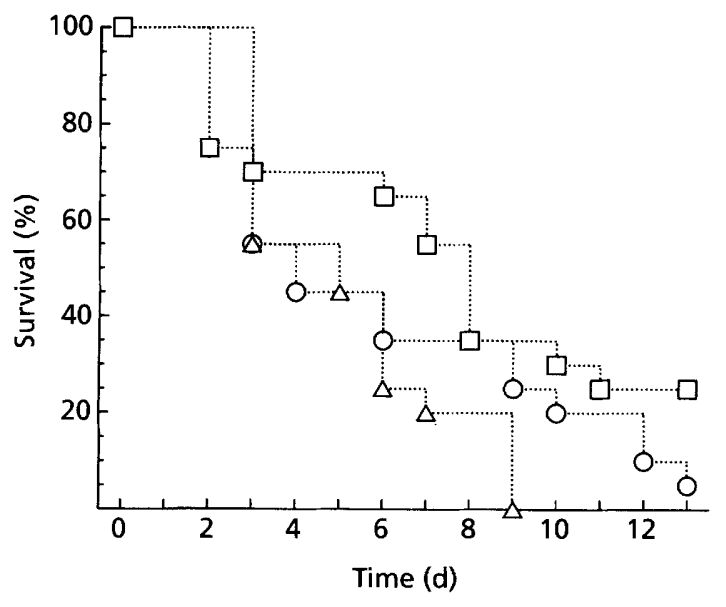

Fig. 5. Pathogenicity of neutral trehalase mutants. Survival of mice $(n=20)$ infected with wild-type C. albicans SC5314 $(\square)$ and isogenic trehalase deletion mutants CAl-4 NTC1/Antc1::hisG-URA3-hisG ( $\triangle$, heterozygous strain) and CAI-4 Antc1::hisG/Dntc1::hisG-URA3-hisG (O, homozygous strain).

phorylation and neutral trehalase was partially purified by anion exchange chromatography to avoid crosscontamination with acid trehalase as described in Methods. Extracts from mutants homozygous for neutral trehalase mutation showed $1.4 \%$ neutral trehalase activity of the corresponding CAI- $4[0.395 \pm 0.085$ milliunits (mg protein $)^{-1}$ and $28 \pm 2$ milliunits (mg protein) ${ }^{-1}$, respectively]. Extracts from heterozygous mutants showed $52 \%$ activity $[14.5 \pm 2.5$ milliunits (mg protein $)^{-1}$.

Activity of partially purified neutral trehalase was reduced to $50 \%$ by validamycin $\mathrm{A}$ at $0.5 \mu \mathrm{g} \mathrm{m}^{-1}$.

\section{Pathogenicity of neutral trehalase mutants}

C. albicans mutants were tested for pathogenicity in the mouse candidiasis model. No significant differences $(P \leqslant 0.05)$ were observed between survival curves of mice infected with the wild-type strain C. albicans SC5314, with C. albicans CAI-4 (NTC1/Antc1:: hisG-URA3his $G$ ), heterozygous for neutral trehalase mutation and

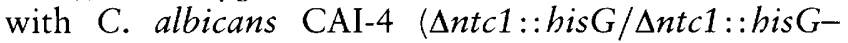
URA3-hisG), homozygous for neutral trehalase mutation (Fig. 5).

\section{DISCUSSION}

Screening systems based on molecular targets of $C$. albicans, the major fungal pathogen of humans, may result in identification of new antifungal drugs. After selection of a potential target, the influence on the pathogenicity of C. albicans has to be evaluated by a combination of molecular methods and tests of pathogenicity. Therefore, the NTC1 gene encoding the 
C. albicans neutral trehalase was cloned and disrupted. The resulting heterozygous and homozygous $n t c 1$ mutant strains were tested for pathogenicity in a mouse model for systemic candidiasis.

The deduced amino acid sequence of the Candida neutral trehalase has $57 \%$ identity to $S$. cerevisiae Nth1p. Multiple alignment of neutral trehalases from S. cerevisiae (Kopp et al., 1993, 1994), E. coli (Gutierrez et al., 1989), Tenebrio molitor (Takiguchi et al., 1992), rabbit (Ruf et al., 1990) and C. albicans shows eight central and C-terminal regions which contain three to seven similar amino acids (Fig. 2). It is unknown whether these conserved sequences are functional regions of neutral trehalase.

A second possible start codon was found at position +25 of the nucleotide sequence of the NTC1 gene. On the basis of the primer extension analysis results it is not possible to establish which start codon is used. However, considering that a part (Arg/Arg) of a putative phosphorylation site (Arg/Arg/Met/Ser, doubly underlined in Fig. 2) which also exists in the $S$. cerevisiae neutral trehalase (Arg/Arg/Leu/Ser) (Kopp et al., 1994) was identified between the two possible start codons, we assume that the longer ORF is transcribed in C. albicans.

A molecular mass of $104 \mathrm{kDa}$ was calculated from the deduced amino acid sequence of the NTC1 gene. Compared with the calculated molecular mass of the neutral trehalase of $S$. cerevisiae (Kopp et al., 1993, 1994), Ntc1p is $18 \mathrm{kDa}$ larger. In agreement with this calculated molecular mass, preliminary data from ultrafiltration, size exclusion chromatography and SDSPAGE of partially purified neutral trehalase from $C$. albicans indicate a molecular mass of about $100 \mathrm{kDa}$ for the denatured protein. Under non-denaturing conditions the native enzyme has a molecular mass of about $200-250 \mathrm{kDa}$. As in S. cerevisiae, the active form of the C. albicans enzyme therefore seems to be a dimer.

Northern blot analysis showed a single band of approximately $3 \cdot 2 \mathrm{~kb}$. Considering the $2724 \mathrm{bp}$ of the ORF, upstream (130 bases) and downstream (196 bases) nucleotides and polyadenylation, this value corresponds to the expected size of the mRNA for the neutral trehalase.

The N-terminal part of Ntc1p contains two possible phosphorylation sites (Rittenhouse et al., 1986). The Nth1p from S. cerevisiae also has two phosphorylation sites in this region (Kopp et al., 1993, 1994). One or both of these probably mediate the increase in trehalase activity by cAMP-dependent phosphorylation of a serine residue (Van Solingen \& van der Plaat, 1975; App \& Holzer, 1989). Experiments with crude extract from $C$. albicans wild-type cells showed a similar activation of neutral trehalase by cAMP-dependent phosphorylation. Treatment with alkaline phosphatase destroyed the activity of C. albicans neutral trehalase (data not shown).

To determine whether the NTC1 gene is essential for $C$. albicans growth and pathogenicity, gene disruption was performed. In C. albicans, which is a diploid organism without a detectable sexual life cycle, sequential disruption of the two alleles of the host gene is required. This can be achieved by repeated homologous recombination between the resident genes and truncated alleles using the Ura-blasting procedure developed by Fonzi \& Irvine (1993).

Disruption of both alleles was confirmed by Southern blot analysis, PCR and activity assays of neutral trehalase. As the enzyme is probably regulated by phosphorylation, activity measurements in unphosphorylated extracts cannot prove a reduction in enzyme content in mutant cells. However, results of assays with phosphorylated and partially purified samples should correspond to the enzyme content of wild-type and mutant cells.

Our results indicate that the neutral trehalase encoded by the NTC1 gene is not essential for growth and pathogenicity of C. albicans. We assume that C. albicans can compensate for the absence of neutral trehalase by an unknown gene or pathway because the trehalose level is not significantly increased in trehalase mutants (data not shown) and, after a slight delay, the growth rate of the homozygous mutant strain was identical with the wild-type strain in trehalose medium at different temperatures and after heat shock.

Under normal conditions we found no neutral trehalase activity in the homozygous mutant strain. However, C. albicans could have a second trehalase gene like YBR0106 in S. cerevisiae that is activated under specific conditions. The homology between NTC1 and this putative second trehalase gene in C. albicans must be low, because a low-stringency Southern analysis showed no second signal.

The delay in hyphal formation of homozygous mutant strains after induction with $\mathrm{N}$-acetylglucosamine and serum indicates that the initiation of the dimorphic switch may be connected with the mobilization of trehalose by the neutral trehalase. The constant level of NTC1 mRNA in yeast and hyphal growing cells indicates that neutral trehalase activity is regulated by protein phosphorylation as in S. cerevisiae.

No significant differences between survival curves of mice infected with the wild-type strain SC5314 and with the heterozygous/homozygous $n t c 1$ mutant strains were observed. We used only $\mathrm{Ura}^{+}$strains because the Ura ${ }^{-}$ strain C. albicans CAI-4 showed no pathogenicity in a rat candidiasis model (Cole et al., 1995). However, an effect of the delay in hyphal formation on the pathogenicity of the mutant strains could not be detected using an intravenous injection model of virulence.

Nevertheless, trehalose metabolism remains an interesting target for antifungal drugs. S. cerevisiae mutants defective in trehalose synthesis are unable to grow in the presence of glucose at physiologically relevant concentrations (Hohmann et al., 1994). The gene responsible, 
GGS1/TPS1, encodes the small subunit of trehalose synthase (Van Aelst et al., 1993). This enzyme could be a target for the development of fungus-specific screening systems.

\section{ACKNOWLEDGEMENTS}

We thank Bill Fonzi for providing C. albicans CAI-4 and plasmid pMB-7, Rolf Swoboda for the C. albicans cDNA library and helpful discussions, as well as Cornelia Kurischko and Ulrike Gausman for critical reading of the manuscript. Special thanks to Stephan Badock, Katrin Beer, Andrea Hartmann and Monika Nguyen for technical assistance.

This work was supported by Bayer AG.

\section{REFERENCES}

App, H. \& Holzer, H. (1989). Purification and characterization of neutral trehalase from the ABYS1 mutant. J Biol Chem 264, 17583-17588.

Arguelles, J. C. \& Gacto, M. (1985). Evidence for regulatory trehalase activity in Candida utilis. Can J Microbiol 31, 529-537.

Arnold, W. N. \& McLellan, M. N. (1975). Trehalose and glycogen levels during the initial stages of growth of Candida albicans. Physiol Chem Phys 7, 369-380.

Asano, N., Yamaguchi, T. \& Kameda, Y. (1987). Effect of validamycins on glycohydrolases of Rhizoctonia solani.J Antibiot 4, 526-532.

Barton, R. C. \& Scherer, S. (1993). Induced chromosome rearrangements and morphologic variations in Candida albicans. $J$ Bacteriol 176, 756-763.

Boeke, J. D., LaCroute, F. \& Fink, G. R. (1984). A positive selection for mutants lacking orotidine- 5 '-phosphate decarboxylase activity in yeast: 5-fluoro-orotic acid resistance. Mol Gen Genet 197, 345-346.

Carrillo, D., Vincente-Soler, J., Fernandez, J., Soto, T., Cansado, J. $\&$ Gacto, M. (1995). Activation of cytoplasmic trehalase by cyclicAMP-dependent and cyclic-AMP-independent signalling pathways in the yeast Candida utilis. Microbiology 141, 679-686.

Cole, M. F., Bowen, W. H., Zhao, X. \& Cihlar, R. L. (1995). Avirulence of Candida albicans auxotrophic mutants in a rat model of oropharyngeal candidiasis. FEMS Microbiol Lett 126, 177-180.

Fonzi, W. A. \& Irvine, M. Y. (1993). Isogenic strain construction and gene mapping in Candida albicans. Genetics 134, 717-728.

Forstner, G. G., Sabsin, S. M. \& Isselbacher, K. L. (1968). Rat intestinal microvillus membranes: purification and biochemical characterization. Biochem J 106, 381-390.

George, S. G. \& Kenny, A. J. (1973). Studies on the enzymology of purified preparations of brush border from rabbit kidney. Biochem J 134, 43-57.

Gutierrez, C., Ardourel, M., Bremer, E., Middendorf, A., Boos, W. \& Ehmann, U. (1989). Analysis and DNA sequence of the osmoregulated treA gene encoding the periplasmic trehalase of Escherichia coli. Mol Gen Genet 217, 347-354.

Hill, E. P. \& Sussmann, A. S. (1963). Purification and properties of trehalase(s) from Neurospora. Arch Biochem Biophys 102, 389-396.

Hohmann, S., Van Dijck, P., Luyten, K. \& Thevelein, J. M. (1994). The byp1-3 allele of the Saccharomyces cerevisiae GGS1/TPS1 gene and its multi-copy suppressor tRNA GLN (CAG): Ggs1/
Tps1 protein levels restraining growth on fermentable sugars and trehalose accumulation. Curr Genet 26, 295-301.

Hottiger, T., Boller, T. \& Wiemken, A. (1987). Correlation of trehalose content and heat resistance in yeast mutants altered in the RAS/adenylate cyclase pathway: is trehalose a thermoprotectant? FEBS Lett 220, 113-115.

Killick, K. A. (1985). Alterations in trehalase solubility during development in the cellular slime mould Dictyostelium discoideum. J Gen Microbiol 131, 273-278.

Kopp, M., Müler, H. \& Holzer, H. (1993). Molecular analysis of the neutral trehalase gene from Saccharomyces cerevisiae. J Biol Chem 268, 4766-4774.

Kopp, M., Nwaka, S. \& Holzer, H. (1994). Corrected sequence of the yeast neutral trehalase-encoding gene (NTH1): biological implication. Gene 150, 403-404.

Kyosseva, S. V., Kyossev, Z. N. \& Elbein, A. D. (1995). Inhibitors of pig kidney trehalase. Arch Biochem Biophys 316, 821-826.

Lloyd, A. T. \& Sharp, P. M. (1992). Evolution of codon usage patterns: the extent and nature of divergence between Candida albicans and Saccharomyces cerevisiae. Nucleic Acids Res 20, 5289-5295.

Luces, T. M. \& Phaff, H. J. (1952). Characteristics of trehalase in Candida tropicalis. Antonie Leeuwenhoek 18, 323-335.

Merdinger, E., Lange, C. F. \& Booker, B. F. (1971). Isolation and identification of trehalase from Pullularia pullans.J Bacteriol 106, 1034-1035.

Mittenbühler, K. \& Holzer, H. (1988). Purification and characterization of acid trehalase from the yeast suc2 mutant. $J$ Biol Chem 263, 8537-8543.

Plempel, M. (1984). Antimycotic activity of Bay N 7133 in animal experiments. J Antimicrob Chemother 13, 447-463.

Retief, L. W. \& Hewitt, P. H. (1973). Purification and properties of trehalase from the harvester termite Trinervitermes trinervoides. Insect Biochem 3, 345-352.

Rittenhouse, J., Harrsch, P. B., Kim, J. N. \& Marcus, F. (1986). Amino acid sequence of the phosphorylation site of yeast (Saccharomyces cerevisiae) fructose-1,6-bisphosphatase. J Biol Chem 261, 3939-3943.

Ruf, J., Wacker, H., James, P., Maffia, M., Seiler, P., Galand, G., von Kieckenbusch, A., Semenza, G. \& Mantei, N. (1990). Rabbit small intestinal trehalase. Purification, cDNA cloning, expression, and verification of glycosylphosphatidylinositol anchoring. $J$ Biol Chem 265, 15034-15039.

Sacktor, B. (1968). Trehalase and the transport of glucose in the mammalian kidney and intestine. Proc Natl Acad Sci USA 60, 1007-1014.

Sambrook, J., Fritsch, E. F. \& Maniatis, T. (1989). Molecular Cloning: a Laboratory Manual, 2nd edn. Cold Spring Harbor, NY: Cold Spring Harbor Laboratory.

Sanger, F., Nicklen, S. \& Coulson, A. R. (1977). DNA sequencing with chain-terminating inhibitors. Proc Natl Acad Sci USA 74, 5463-5467.

Soll, D. R. (1986). The regulation of cellular differentiation in the dimorphic yeast Candida albicans. Bioessays 5, 5-11.

Swoboda, R. K., Bertram, G., Hollander, H., Greenspan, D., Greenspan, J. S., Gow, N. A. R., Gooday, G. W. \& Brown, A. J. P. (1993). Glycolytic enzymes of Candida albicans are nonubiquitous immunogens during candidiasis. Infect Immun 61, $4263-4271$.

Swoboda, R. K., Bertram, G., Budge, S., Gow., N. A. R., Gooday, G. W. \& Brown, A. J. P. (1995). Structure and regulation of the 
HSP90 gene from the pathogenic fungus Candida albicans. Infect Immun 63, 4506-4514.

Takiguchi, M., Niimi, T., Su, Z.-H. \& Yaginuma, T. (1992). Trehalase from male accessory gland of an insect, Tenebrio molitor. Biochem J 288, 19-22.

Thevelein, J. M. (1984). Regulation of trehalose mobilization in fungi. Microbiol Rev 48, 42-59.

Van Aelst, L., Hohmann, S., Bulaya, B. \& 15 other authors (1993). Molecular cloning of a gene involved in glucose sensing in the yeast Saccharomyces cerevisiae. Mol Microbiol 8, 927-943.
Van Solingen, P. \& van der Plaat, J. B. (1975). Partial purification of the protein system controlling the breakdown of trehalose in Bakers yeast. Biochem Biophys Res Commun 62, 553-560.

Wiemken, A. (1990). Trehalose in yeast, stress protectant rather than reserve carbohydrate. Antonie Leeuwenhoek 58, 209-217.

Wolfe, K. H. \& Lohan, J. E. (1994). Sequence around the centromere of Saccharomyces cerevisiae chromosome II: similarity of CEN2 to CEN4. Yeast 10, 41-46.

Received 28 April 1997; revised 30 June 1997; accepted 30 July 1997. 